\title{
PENGARUH KONSEP DIRI DAN KECEMASAN BELAJAR TERHADAP KEMAMPUAN MENYELESAIKAN MASALAH MATEMATIKA PADA SISWA MADRASAH ALIYAH NEGERI DI JAKARTA BARAT.
}

\author{
MUSLIHATUL HIDAYAH \\ muslihatulhidayah@gmail.com \\ Program Studi Teknik Informatika, Fakultas Teknik dan MIPA \\ Universitas Indraprasta PGRI Jakarta
}

\begin{abstract}
Abstrak. Tujuan penelitian ini adalah untuk mengetahui pengaruh langsung konsep diri terhadap kemampuan pemecahan masalah matematika, pengaruh langsung kecemasan belajar terhadap kemampuan pemecahan masalah matematika dan pengaruh langsung konsep diri terhadap kecemasan belajar serta pengaruh tidak langsung konsep diri terhadap kemampuan pemecahan masalah matematika melalui kecemasan belajar.Metode penelitian yang digunakan teknik penelitian survei. Sampel berjumlah 95 responden yang dipilih secara acak dan proporsional dari seluruh siswa di Madrasah Aliyah Negeri Jakarta Barat. Analisis data menggunakan metode analisis jalur dengan pendekatan analisis regresi dengan bantuan SPSS 20 dan uji-t sebagai uji statistik. Hasil penelitian menunjukkan: 1) Tidak terdapat pengaruh langsung yang signifikan konsep diri terhadap kemampuan pemecahan masalah matematika 2) Tidak terdapat pengaruh langsung yang signifikan terhadap kecemasan belajar terhadap kemampuan pemecahan masalah matematika 3)Terdapat pengaruh tidak langsung yang signifikan konsep diriterhadap kecemasan belajar 4) Tidak terdapat pengaruh tidak langsung yang signifikan konsep diri terhadap kemampuan pemecahan masalah matematikamelalui kecemasan belajar.
\end{abstract}

Kata Kunci: Konsep Diri, KecemasanBelajar, Kemampuan Menyelesaikan Masalah Matematika.

\section{PENDAHULUAN}

Pendidikan merupakan hal yang utama dan terutama di dalam kehidupan era masa sekarang ini. Sejauh kita memandang maka sejauh itu pula kita harus melengkapi diri kita dengan berbagai pendidikan.

Konsep diri memiliki peranan penting dalam menentukan perilaku individu sebagai cermin bagi individu dalam memandang dirinya. Individu akan bereaksi terhadap lingkungannya sesuai dengan konsep dirinya, pembentukan konsep diri memudahkan interaksi sosial sehingga individu yang bersangkutan dapat mengantisipasi reaksi orang lain.

Menilik dari hasil Ujian Nasional di DKI Jakarta baru-baru ini, nilai UN yang dinilai kurang adalah Matematika. Pertanyaannya adalah mengapa Matematika? Sementara penguasaan matematika bagi bangsa Indonesia telah dipersiapkan melalui Sekolah Formal sejak dini, dari tingkat Sekolah Dasar hingga jenjang Sekolah Menengah Atas, materi matematika telah disusun dan diajarkan secara sistematis dan berkelanjutan sehingga diharapkan lebih mudah mempelajarinya. Akan tetapi, di lapangan banyak peserta didik yang bersikap negatif terhadap matematika. Sebagian besar menganggap matematika sebagai momok yang sulit untuk dipelajari apalagi dikuasai dan ini berkesinambungan terhadap generasi temurunnya. Akhirnya peserta didik tidak berani untuk mempelajari matematika sehingga membuat hasil belajarnya menurun.

Dalam pembelajaran matematika, masalah dapat disajikan dalam bentuk soal non rutin yang berupa soal cerita, penggambaran fenomena atau kejadian, ilustrasi gambar 
atau teka-teki. Oleh karenanya pemecahan masalah merupakan bagian dari kurikulum matematika yang sangat penting karena dalam proses pembelajaran maupun penyelesaian.

Di tingkat SMA/MAN khususnya MAN di wilayah Kecamatan Jakarta Barat, dari survey beberapa guru yang bersangkutan penyusun melihat siswa-siswinya di Sekolah tersebut masih mengalami kesulitan dalam menyelesaikan persoalan terutama di bidang matematika karena merupakan bidang studi yang dianggap berat dan sulit dipelajari dan menuntut penalaran, pembentukan sikap dan keterampilan dalam penerapannya akhirnya peserta didik merasa terbebani dan tidak dapat bertanggungjawab tentang nilainya atau bahasa lain nilai matematikanya yang kurang optimal. Kesimpulannya adalah konsep diri yang positif akan pandangan pelajaran matematika meminimalisir kecemasan belajar matematika yang akan berpengaruh terhadap kemampuan siswa memecahkan masalah.

Hal inilah yang mendorong penyusun ingin melakukan sebuah penelitian yang berjudul "Pengaruh Konsep Diri dan Kecemasan Belajar terhadap Kemampuan Menyelesaikan Masalah Matematika pada Siswa Madrasah Aliyah Negeri di Jakarta Barat”.

\section{TINJAUAN PUSTAKA}

\section{Teori Kemampuan Pemecahan Masalah Matematika}

Menurut John Dewey (2007: 34) pemecahan masalah merupakan proses mental yang meliputi tiga aspek besar yaitu menemukan, merumuskan, menerapkkan solusi masalah. Pemecahan masalah merupakan fungsi intelektual paling kompleks dari semua fungsi intelektual tinggi manusia atau proses kognitif yang memerlukan kontrol dan keterampilan fundamental.

Penyusun mengamati terhadap peserta didik saya dalam proses pembelajaran dan terjadi pada sebuah kelas $\mathrm{X}$ semester ganjil, salah satu mata pelajaran matematika yang ada pada semester ganjil ini adalah pada materi fungsi eksponen dan logaritma.

Fungsi eksponen adalah salah satu fungsi yang cukup penting dalam matematika. Beberapa contoh fungsi eksponen yaitu $y=f(x)=5^{x}, y=f(x)=e^{x}$. dan $y=f(x)=1^{x}$. Fungsi eksponen banyak sekali penerapannya dan tidak hanya dalam matematika saja tetapi banyak pula berkaitan dengan pertumbuhan dan peluruhan.

Salah satu contoh soal sebuah bola basket dijatuhkan dari ketinggian 3 meter dan setiap kali jatuh ke lantai, bola itu naik setinggi 65\% dari ketinggian sebelumnya, selanjutnya kita akan menentukan model jatuhnya bola dalam bentuk peluruhan eksponen sebagai suatu fungsi tinggi bola $\mathrm{T}$ (meter) dari banyaknya jatuhan $\mathrm{n}$.

Maka penyelesaiannya adalah sebagai berikut : Bola basket yang dijatuhkan dari ketinggian 3 meter dengan setiap kali jatuhnya naik setinggi 65\% dari ketinggian sebelumnya adalah fungsi eksponen dengan tinggi bola (dalam meter) setelah :

Jatuh ke-1 adalah $3(0,65)=1,95$

Jatuh ke-2 adalah $3(0,65)(0,65)=3(0,65)^{2}=1,2675$

Jatuh ke-3 adalah $3(0,65)(0,65)(0,65)=3(0,65)^{3}=0,8239$

Jatuh ke-n adalah $3(0,65)(0,65) \ldots(0,65)=3(0,65)^{\mathrm{n}}$

Jadi tinggi bola $\mathrm{T}$ (meter) merupakan fungsi dari banyaknya jatuhan $\mathrm{n}$ dengan persamaan $\mathrm{T}=3(0,65)^{\mathrm{n}}$.

Selain itu kita akan melihat bahwa fungsi eksponen erat kaitannya dengan fungsi logaritma. Misalnya dalam suatu kota jumlah penduduk tahun 2012 mencapai 2 juta jiwa. Bila jumlah penduduk di kota tersebut meningkat dengan laju 2,5\% pertahun dan andaikan laju pertumbuhan itu tetap sebesar itu dalam setiap tahunnya, maka berapa banyaknya penduduk di kota tersebut pada tahun 2017 ? Pertumbuhan penduduk pada dasarnya sama dengan pertambahan tabungan yang disimpan di Bank. Jadi apabila 
banyaknya penduduk mula-mula $\mathrm{P}$ dengan tingkat kenaikan penduduk $1 \%$, sedangkan banyaknya penduduk setelah $t$ tahun adalah $\mathrm{P}_{t}$, maka banyaknya penduduk pada saat $t$ tahun adalah $\mathrm{P}_{t}=\mathrm{P}(1+\mathrm{I}){ }^{t}$. Jadi banyaknya penduduk di kota tersebut pada tahun 2017 (setelah 5 tahun) menjadi

$$
\begin{aligned}
& \mathrm{P}_{5}=2000000(1+00,025)^{5} \\
& =2.10^{6} .(1,025)^{5} \\
& \text { Jika dengan bantuan logaritma didapatkan : } \\
& \begin{aligned}
\mathrm{P} 5=2 & .10^{6}(1,025)^{5} \\
\log \mathrm{P}_{5} & =\log 2+\log 106+\log (1,025)^{5} \\
& =\log 2+6 \log 10+5 \log (1,025) \\
& =0,3010299+6+5(0,0107238) \\
& =0,3010299+6+0,5361932
\end{aligned} \\
& \begin{aligned}
\log \mathrm{P}_{5} & =6,354 \\
\mathrm{P}_{5} & =2,262816 \text { (pembulatan) }
\end{aligned}
\end{aligned}
$$

Jadi banyaknya penduduk di kota tersebut setelah 5 tahun menjadi 2.262.816 jiwa.

Seperti dijelaskan di atas dalam fungsi eksponen, kita tidak bekerja secara langsung dengan bilangan melainkan bekerja dengan menggunakan simbol, variabel dan elemenelemen himpunan. Sebagai contoh penambahan dan perkalian dipandang sebagai operasi secara umum.

Ada beberapa masalah yang menyebabkan peserta didik menjadi salah dalam penyelesaian soal yang paling mendasar adalah cara didalam mengoperasikan fungsi eksponen dan logaritma, bukan dalam pemahaman materinya. Siswa yang tidak siap menerima ilmu eksponen akan menjadi kabur dalam menerima materi. Sehingga melupakan aturan yang tak jelas atau memilih cara yang "lebih mudah" walaupun pada kenyataannya merupakan aturan yang tidak benar dan akhirnyapun banyak dari mereka yang melakukan kesalahan baik secara konseptual maupun prosedural.

Berdasarkan uraian di atas disimpulkan bahwa kemampuan menyelesaikan masalah merupakan proses mental yang tinggi dan kompleks yaitu melibatkan visualisasi, imajinasi, abstraksi dan asosiasi informasi yang diberikan.

\section{Teori Konsep Diri}

Secara garis besar, istilah konsep memiliki arti gambaran, proses atau hal-hal yang digunakan oleh akal budi untuk memahami sesuatu. Istilah diri berarti bagian-bagian dari individu yang terpisah dari yang lain. Konsep diri dapat diartikan sebagai gambaran seseorang mengenai dirinya sendiri atau penilaian terhadap dirinya sendiri.

Menurut Stuart dan Sundeen (dalam Dacey \& Kenny, 2005: 344), konsep diri adalah semua ide, pikiran, kepercayaan dan pendirian yang diketahui individu tentang dirinya dan mempengaruhi individu dalam berhubungan dengan orang lain.

Disimpulkan bahwa konsep diri adalah gambaran yang ada pada diri individu yang berisikan tentang bagaimana individu melihat dirinya sendiri sebagai pribadi yang disebut dengan pengetahuan diri, bagaimana individu merasa atas dirinya yang merupakan penilaian diri sendiri.

\section{Teori Kecemasan Belajar Matematika}

Kecemasan matematika (math anxiety) telah didefinisikan sebagai perasaan ketegangan dan kecemasan yang mengganggu terkait manipulasi angka dan pemecahan masalah matematika dalam berbagai kehidupan sehari-hari maupun situasi akademik. Selanjutnya disebutkan juga bahwa kecemasan matematika dapat menyebabkan lupa dan kehilangan akan kepercayaan diri (Tobias S. dalam Curtain-Philips, 2012: 109). Mathematical Anxiety atau mathphobia menurut Reys, dkk. (1998) (dalam Afgani D. 
Jarnawi, 2011: 98) adalah ketakutan terhadap matematika atau prasangka negatif tentang matematika.

Ashcraft (2002: 1) mendefinisikan kecemasan belajar matematika sebagai perasaan ketegangan, cemas atau ketakutan yang mengganggu kinerja matematika. Kecemasan belajar matematika banyak terjadi dikalangan remaja sebagai peserta didik karena pada periode ini merupakan periode yang sudah mulai menggabungkan pengalaman yang diperoleh sebelumnya dengan tantangan saat ini dan memikirkan keadaan di masa yang akan datang maka apabila pada perkembangannya tidak berjalan mulus, hal inilah yang menimbulkan kecemasan dalam belajar matematika.

Dari uraian diatas dapat dibuat sintesis bahwa kecemasan dalam belajar matematika adalah perasaan cemas atau takut yang menimbulkan ketidaktenteraman hati ketika berhubungan dengan matematika sebagai akibat dari kurangnya ketertarikan terhadap matematika karena pengaruh belajar dimasa lampau.

\section{METODE}

Penelitian ini menggunakan teknik penelitian survei (survey research) yaitu penelitian dengan tidak melakukan perubahan (tidak ada perlakuan khusus) terhadap variabel-variabel yang diteliti.

Metode dalam pengambilan sampel dalam penelitian ini yaitu teknik probability sampling (sampling random) yaitu cara pengambilan sampel dengan semua objek atau elemen populasi memiliki kesempatan yang sama untuk dipilih sebagai sampel. Pengambilan sampel ini menggunakan cluster random sampling (sampel berkelompok) yaitu pengambilan sampel dari beberapa subpopulasi namun kelompok tersebut tidak menggambarkan tingkatan. Pengambilan sampel diakukan secara acak dan proporsional (subsampel sebanding dengan subpopulasi).

Secara garis besar, penyelesaian masalah dengan analisis jalur (path analysis) dapat diselesaikan melalui pendekatan korelasi sederhana dan pendekatan regresi linear(Supardi, 276 : 2012). Dalam penelitian ini penyelesaian dilakukan melalui pendekatan regresi linier dengan bantuan SPSS 20 dan Ms. Excel 2007. Yaitu menghitung koefisien jalur $p_{21}$ dan koefisien jalur $p_{21}$.

\section{HASIL PENELITIAN DAN PEMBAHASAN \\ Karakteristik Responden}

Penelitian ini dilakukan di Madrasah Aliyah Negeri Jakarta Barat. Banyaknya responden adalah 95 peserta didik pada Madrasah Aliyah Negeri 1 sebanyak 24 siswa, Madrasah Aliyah Negeri 22 sebanyak 37 siswa dan Madrasah Aliyah Negeri 12 sebanyak 34 siswa. Pada halaman ini ditampilkan deskripsi statistik dari hasil perhitungan dan pengujian yang dilakukan dengan bantuan Microsoft Excel 2007 dan SPSS 20, serta analisis dan interpretasinya.

\section{Analisis Data Variabel Konsep Diri $\left(\mathrm{X}_{1}\right)$}

Konsep diri yang diperoleh dari para responden penelitian mempunyai rata-rata 97,44 dengan simpangan baku 7,936 serta perolehan konsep diri minimum 76 dan maksimum 115. Hal ini berarti nilai range atau rentangnya adalah 39 (maximum $=115$ dikurangi minimum $=76$ ), angka simpangan baku sebesar 7,936 atau sama dengan 8,144 $\%$ dari rata-rata, hal ini menunjukkan perbedaan konsep diri dari responden tergolong rendah.

Dari deskripsi data juga dapat dilihat bahwa antara nilai rata-rata dan median hampir sama yaitu 97,44 dan 99,00. Hal ini menunjukkan bahwa data skor konsep diri pada penelitian ini cukup respresentatif. Sedangkan skor yang berada diatas rata-rata 
lebih banyak dibanding yang berada dibawah rata-rata, menunjukkan bahwa peserta didik yang memiliki konsep diri tinggi lebih banyak daripada peserta didik yang memiliki konsep diri rendah.

\section{Analisis Data Variabel Kecemasan Belajar $\left(\mathrm{X}_{2}\right)$}

Kecemasan belajar yang diperoleh dari para responden penelitian mempunyai ratarata 99,57 dengan simpangan baku 8,283 serta perolehan kecemasan belajar minimum 79 dan maksimum 121. Hal ini berarti nilai range atau rentangnya adalah 42 (maximum = 121 dikurangi minimum $=79$ ), angka simpangan baku sebesar 8,283 atau sama dengan 8,318 \% dari rata-rata, hal ini menunjukkan perbedaan kecemasan belajar dari responden tergolong rendah.

Dari deskripsi data juga dapat dilihat bahwa antara nilai rata-rata dan median hampir sama yaitu 99,57 dan 99,00. Hal ini menunjukkan bahwa data skor kecemasan belajar pada penelitian ini cukup respresentatif. Sedangkan skor yang berada diatas ratarata lebih banyak dibanding yang berada dibawah rata-rata, menunjukkan bahwa peseta didik yang memiliki kecemasan belajar tinggi lebih banyak daripada peserta didik yang memiliki kecemasan belajar rendah.

\section{Analisis Data Variabel Kemampuan Penyelesaian Masalah Matematika (Y)}

Kemampuan penyelesaian masalah matematika yang diperoleh dari para responden penelitian mempunyai rata-rata 84,4917 dengan simpangan baku 9,96201 serta perolehan kemampuan penyelesaian masalah matematika minimum 60,00 dan maksimum 96,67. Hal ini berarti nilai range atau rentangnya adalah 36,67 (maximum $=96,67$ dikurangi minimum $=60,00$ ), angka simpangan baku sebesar 9,96201 atau sama dengan 11,791\% dari rata-rata, hal ini menunjukkan perbedaan kecemasan belajar dari responden tergolong sedang dan beragam.

Dari deskripsi data juga dapat dilihat bahwa antara nilai rata-rata dan median hampir sama yaitu 84,4917 dan 86,6700. Hal ini menunjukkan bahwa data skor kemampuan penyelesaian masalah matematika pada penelitian ini cukup respresentatif. Sedangkan skor yang berada diatas rata-rata lebih banyak dibanding yang berada dibawah rata-rata, menunjukkan bahwa peserta didik yang memiliki kemampuan penyelesaian masalah matematika yang tinggi lebih banyak daripada peserta didik yang memiliki kemampuan penyelesaian masalah matematika yang rendah.

\section{Uji Persyaratan Analisis}

\section{Uji Normalitas}

Dari hasil perhitungan menunjukkan bahwa nilai Sig untuk variabel konsep diri sebesar 0,227, nilai Sig untuk variabel kecemasan belajar sebesar 0,122 dan nilai Sig variabel kemampuan penyelesaian masalah matematika sebesar 0,127. Karena nilai Sig ketiga variabel tersebut bernilai $>0,05$ artinya sampel data ketiga variabel tersebut berasal dari populasi berdistribusi normal.

\section{Uji Kelinearan Regresi}

\section{Linearitas Garis Regresi Hubungan antara Variabel $\mathrm{X}_{1}$ dengan Variabel $\mathrm{Y}$}

Dari hasil perhitungan menunjukkan hubungan antara konsep diri $\left(\mathrm{X}_{1}\right)$ dengan kemampuan penyelesaian masalah matematika (Y) menghasilkan nilai $F=1,094$ dengan nilai probabilitas (Sig $p=0,373$ ). Karena nilai signifikansi $p=0,373>0,05$ maka dengan demikian dapat disimpulkan $\mathrm{H}_{0}$ diterima artinya model regresi bersifat linear.

\section{Linearitas Garis Regresi Hubungan antara Variabel $\mathrm{X}_{2}$ dengan Variabel $\mathrm{Y}$}


Dari hasil perhitungan menunjukkan hubungan antara kecemasan belajar $\left(\mathrm{X}_{2}\right)$ dengan kemampuan penyelesaian masalah matematika $(\mathrm{Y})$ menghasilkan nilai $F=1,275$ dengan nilai probabilitas (Sig $p=0,206$ ). Karena nilai signifikansi $p=0,206>0,05$ maka dengan demikian dapat disimpulkan $\mathrm{H}_{0}$ diterima artinya model regresi bersifat linear.

\section{Linearitas Garis Regresi Hubungan antara Variabel $\mathrm{X}_{\mathbf{1}}$ dengan Variabel $\mathrm{X}_{\mathbf{2}}$}

Dari hasil perhitungan menunjukkan hubungan antara konsep diri $\left(\mathrm{X}_{1}\right)$ dengan kecemasan belajar $\left(\mathrm{X}_{2}\right)$ menghasilkan nilai $F=0,744$ dengan nilai probabilitas ( $\operatorname{Sig} p=$ 0,804). Karena nilai signifikansi $p=0,804>0,05$ maka dengan demikian dapat disimpulkan $\mathrm{H}_{0}$ diterima artinya model regresi bersifat linear.

\section{Uji Multikolinearitas}

Berdasarkan hasil perhitungan diperoleh nilai tolerance dari variabel konsep diri $\left(\mathrm{X}_{1}\right)$ sebesar 0,745 $>0,1$ dan nilai VIF sebesar 1,342 < 10 artinya variabel tersebut tidak terjadi multikolinearitas, berikutnya berdasarkan hasil perhitungan juga diperoleh nilai tolerance dari variabel kecemasan belajar $\left(\mathrm{X}_{2}\right)$ sebesar 0,745 $>0,1$ dan nilai VIF sebesar 1,342 < 10 artinya variabel tersebut tidak terjadi multikolinearitas.

\section{Pengujian Hipotesis Penelitian}

1. Perolehan Perhitungan Dari Data Mentah Variabel $X_{1}, X_{2}$ dan $Y$ ke dalam Skor Baku

\begin{tabular}{|l|l|l|l|}
\hline$\sum X_{1}=9257,00$ & $\bar{X}_{1}=97,44$ & $S_{X 1}=7,94$ & $\sum Z_{1}=-468,08$ \\
\hline$\sum X_{2}=9459,00$ & $\bar{X}_{2}=99,57$ & $S_{X 1}=8,28$ & $\sum Z_{2}=-362,32$ \\
\hline$\sum Y=7573,37$ & $\bar{Y}=84,15$ & $S_{Y}=10,05$ & $\sum Z_{3}=-2,49$ \\
\hline
\end{tabular}

\section{Menetukan Koefisien Korelasi}

\begin{tabular}{|c|c|c|c|c|}
\hline \multicolumn{5}{|l|}{ Correlations } \\
\hline & & $\begin{array}{l}\text { KONSEP } \\
\text { DIRI }\end{array}$ & $\begin{array}{l}\text { KECEMA- } \\
\text { SAN } \\
\text { BELAJAR }\end{array}$ & $\begin{array}{l}\text { KEMAMPUAN } \\
\text { PENYELE- } \\
\text { SAIAN MASALAH } \\
\text { MATEMATIKA } \\
\end{array}$ \\
\hline \multirow{3}{*}{ KONSEP DIRI } & $\begin{array}{l}\text { Pearson } \\
\text { Correlation }\end{array}$ & 1 & $0,505^{* *}$ & 0,135 \\
\hline & Sig. (1-tailed) & & 0,000 & 0,097 \\
\hline & $\mathrm{N}$ & 95 & 95 & 95 \\
\hline \multirow{3}{*}{$\begin{array}{l}\text { KECEMASAN } \\
\text { BELAJAR }\end{array}$} & $\begin{array}{l}\text { Pearson } \\
\text { Correlation }\end{array}$ & $0,505^{* *}$ & 1 & $-0,070$ \\
\hline & Sig. (1-tailed) & 0,000 & & 0,250 \\
\hline & $\mathrm{N}$ & 95 & 95 & 95 \\
\hline \multirow{3}{*}{$\begin{array}{l}\text { KEMAMPUAN } \\
\text { PENYELESAIAN } \\
\text { MASALAH } \\
\text { MATEMATIKA }\end{array}$} & $\begin{array}{l}\text { Pearson } \\
\text { Correlation }\end{array}$ & 0,135 & $-0,070$ & 1 \\
\hline & Sig. (1-tailed) & 0,097 & 0,250 & \\
\hline & $\mathrm{N}$ & 95 & 95 & 95 \\
\hline
\end{tabular}


Ringkasan Hasil Analisis Korelasi

\begin{tabular}{|l|l|l|}
\hline $\begin{array}{l}\text { Hubungan Antar } \\
\text { Variabel }\end{array}$ & Korelasi & Nilai \\
\hline $\mathrm{X}_{1}$ dengan $\mathrm{Y}$ & $r_{13}$ & 0,135 \\
\hline $\mathrm{X}_{2}$ dengan $\mathrm{Y}$ & $r_{23}$ & $-0,070$ \\
\hline $\mathrm{X}_{1}$ dengan $\mathrm{X}_{2}$ & $r_{12}$ & 0,505 \\
\hline
\end{tabular}

\section{Menentukan Harga Koefisien Jalur}

Perhitungan diterapkan dengan bantuan SPSS 20 dan diperoleh:

Koefisien Jalur $p_{21}$

\begin{tabular}{|c|c|c|c|c|c|}
\hline \multicolumn{6}{|l|}{ Coefficients $^{a}$} \\
\hline \multirow[t]{2}{*}{ Model } & \multicolumn{2}{|c|}{$\begin{array}{l}\text { Unstandardized } \\
\text { Coefficients }\end{array}$} & $\begin{array}{l}\text { Standardized } \\
\text { Coefficients }\end{array}$ & \multirow[t]{2}{*}{$\mathrm{t}$} & \multirow{2}{*}{ Sig. } \\
\hline & $\mathrm{B}$ & Std. Error & Beta & & \\
\hline 1 (Constant) & $\begin{array}{l}\text { 2,952E- } \\
015\end{array}$ & 0,089 & & 0,000 & 1,000 \\
\hline \begin{tabular}{|l} 
KONSEP \\
DIRI
\end{tabular} & 0,505 & $S_{21}=0,090$ & $p_{21}=0,505$ & 5,642 & 0,000 \\
\hline
\end{tabular}

Koefisien Jalur $p_{31}$ dan $p_{32}$

\begin{tabular}{|c|c|c|c|c|c|}
\hline \multicolumn{6}{|l|}{ Coefficients $^{a}$} \\
\hline \multirow[t]{2}{*}{ Model } & \multicolumn{2}{|c|}{$\begin{array}{l}\text { Unstandardized } \\
\text { Coefficients }\end{array}$} & \multirow{2}{*}{$\begin{array}{l}\text { Standardized } \\
\text { Coefficients } \\
\text { Beta } \\
\end{array}$} & \multirow[t]{2}{*}{$\mathrm{t}$} & \multirow[t]{2}{*}{ Sig. } \\
\hline & B & Std. Error & & & \\
\hline 1 (Constant) & $\begin{array}{l}-1,040 \mathrm{E}- \\
015\end{array}$ & 0,101 & & 0,000 & 1,000 \\
\hline KONSEP DIRI & 0,228 & $S_{31}=0,118$ & $p_{31}=0,228$ & 1,932 & 0,056 \\
\hline $\begin{array}{l}\text { KECEMASAN } \\
\text { BELAJAR }\end{array}$ & $-0,185$ & $S_{32}=0,118$ & $p_{32}=-0,185$ & $-1,568$ & 0,120 \\
\hline
\end{tabular}

Sehingga diperoleh koefisien jalur $p_{21}=0,505, p_{31}=0,228$ dan $p_{32}=-0,815$.

\section{Menguji Keberartian Koefisien Jalur}

a) Menguji hipotesis 1

Untuk $\alpha=0,05$ dan $\mathrm{dk}=\mathrm{n}-\mathrm{k}-1=92$ untuk uji dua pihak diperoleh harga $\mathrm{t}_{\text {tabel }}=1,986$. Karena $\left|\mathrm{t}_{\mathrm{h}}\right|<\mathrm{t}_{\mathrm{t}}(1,932<1,986)$ maka $\mathrm{H}_{0}$ ditolak dan dapat disimpulkan bahwa tidak terdapat pengaruh langsung yang signifikan konsep diri $\left(\mathrm{X}_{1}\right)$ terhadap kemampuan pemecahan masalah matematika $(\mathrm{Y})$ atau $\mathrm{H}_{0}: p_{31}=0$

b) Menguji hipotesis 2

Untuk $\alpha=0,05$ dan $\mathrm{dk}=\mathrm{n}-\mathrm{k}-1=92$ untuk uji dua pihak diperoleh harga $\mathrm{t}_{\text {tabel }}=1,986$. Karena $\left|\mathrm{t}_{\mathrm{h}}\right|<\mathrm{t}_{\mathrm{t}}(-1,568<1,986)$ maka $\mathrm{H}_{0}$ diterima dan dapat disimpulkan bahwa tidak terdapat pengaruh langsung yang signifikan kecemasan belajar $\left(\mathrm{X}_{2}\right)$ terhadap kemampuan pemecahan masalah matematika(Y) atau $\mathrm{H}_{o}: p_{32}=0$

c) Menguji hipotesis 3

Untuk $\alpha=0,05$ dan $\mathrm{dk}=\mathrm{n}-\mathrm{k}-1=98$ untuk uji dua pihak diperoleh harga $\mathrm{t}_{\text {tabel }}=1,986$. Karena $\left|\mathrm{t}_{\mathrm{h}}\right|<\mathrm{t}_{\mathrm{t}}(5,642>1,986)$ maka $\mathrm{H}_{0}$ diterima dan dapat disimpulkan bahwa terdapat pengaruh langsung yang signifikan konsep diri $\left(\mathrm{X}_{1}\right)$ terhadap kecemasan belajar $\left(\mathrm{X}_{2}\right)$ atau $\mathrm{H}_{o}: p_{21}=0$ 
d) Menguji hipotesis 4

Koefisien pengaruh tidak langsung konsep diri $\left(\mathrm{X}_{1}\right)$ terhadap kemampuan pemecahan masalah matematika $(\mathrm{Y})$ melalui kecemasan belajar $\left(\mathrm{X}_{2}\right)$ ditentukan dari hasil kali koefisien jalur $X_{1}$ ke $X_{2}$ dan $X_{2}$ ke $Y$ (Supardi, 2012: 292). Koefisien jalur pengaruh tidak langsung $\mathrm{X}_{1}$ ke melalui $\mathrm{X}_{2}$ yaitu :

$p_{321}=p_{21} \cdot p_{32}$

$$
\begin{aligned}
& =(0,505)(-0,185) \\
& =-0,0934
\end{aligned}
$$

Dari data SPSS pada koefisien jalur dilihat pada Standard of Error, adalah untuk mengetahui kekeliruan baku koefisien jalur $p_{21}$ yaitu $S_{p 21}$ sebesar 0,090 dan kekeliruan baku koefisien jalur $p_{32}$ yaitu $S_{p 32}$ sebesar 0,118 . Sehingga didapat simpangan baku gabungan :

$$
\begin{aligned}
& S_{g}=\sqrt{\frac{\left(n_{21}-1\right) S^{2} 21+\left(n_{32}-1\right) S_{32}}{n_{21}+n_{32}-2}} \\
&=\sqrt{\frac{(95-1)(0,090)^{2}+(95-1)(0,118)^{2}}{95+95-2}} \\
&=\sqrt{\frac{0,7614+1,3088}{188}}=0,1049 \\
& \text { maka diperoleh nilai } \mathrm{t}_{\mathrm{h}}=\frac{p_{321}}{S_{g}}=\frac{-0,0934}{0,1049}=-0,8904
\end{aligned}
$$

Untuk $\alpha=0,05$ dan $\mathrm{dk}=\mathrm{n}-\mathrm{k}-1=98$ untuk uji dua pihak diperoleh harga $\mathrm{t}_{\text {tabel }}=1,968$. Karena $\left|\mathrm{t}_{\mathrm{h}}\right|<\mathrm{t}_{\mathrm{t}}(-0,8904<1,968)$ maka $\mathrm{H}_{0}$ diterima dan dapat disimpulkan bahwa tidak terdapat pengaruh tidak langsung yang signifikan konsep diri $\left(\mathrm{X}_{1}\right)$ terhadap kemampuan pemecahan masalah matematika $(\mathrm{Y})$ melalui kecemasan belajar $\left(\mathrm{X}_{2}\right)$ atau $\mathrm{H}_{0}: p_{321} \neq 0$

\section{Pembahasan/ Interpretasi Hasil Penelitian}

Pengaruh Langsung Konsep Diri $\left(\mathrm{X}_{1}\right)$ Terhadap Kemampuan Penyelesaian Masalah Matematika (Y)

Ditemukan bahwa terdapat korelasi yang tidak cukup signifikan konsep diri ( $\left.\mathrm{X}_{1}\right)$ terhadap kemampuan penyelesaian masalah matematika (Y). Hal ini ditunjukkan oleh angka koefisien korelasi $\left(r_{13}\right)$ sebesar 0,135.

Diketahui pula bahwa koefisien jalur $\mathrm{X}_{1}$ terhadap $\mathrm{Y}\left(p_{31}\right)$ sebesar $-0,228$ dan setelah diuji dengan uji-t pengaruh tersebut tidak nyata/ signifikan. Hal tersebut menunjukkan tidak ada pengaruh langsung yang signifikan konsep diri $\left(\mathrm{X}_{1}\right)$ terhadap kemampuan penyelesaian masalah matematika (Y). Hal tersebut terlihat pada kontribusi langsung konsep diri $\left(\mathrm{X}_{1}\right)$ terhadap kemampuan penyelesaian masalah matematika (Y) hanya sebesar $(0,228)^{2} \times 100 \%=5,1984 \%$ sisanya sebesar $94,81 \%$ dipengaruhi oleh faktor lain yang tidak dijelaskan dalam penelitian ini.

\section{Pengaruh Langsung Kecemasan Belajar $\left(\mathrm{X}_{2}\right)$ Terhadap Kemampuan Penyelesaian Masalah Matematika(Y)}

Ditemukan bahwa terdapat korelasi yang tidak cukup signifikan kecemasan belajar $\left(\mathrm{X}_{2}\right)$ terhadap kemampuan penyelesaian masalah matematika $(\mathrm{Y})$. Hal ini ditunjukkan oleh angka koefisien korelasi $\left(r_{23}\right)$ sebesar $-0,070$.

Namun demikian, diketahui pula bahwa koefisien jalur $\mathrm{X}_{1}$ terhadap $\mathrm{Y}\left(p_{32}\right)$ sebesar $-0,185$ dan setelah diuji dengan uji-t pengaruh tersebut tidak nyata/ signifikan. Hal tersebut menunjukkan tidak ada pengaruh langsung yang signifikan kecemasan belajar $\left(\mathrm{X}_{2}\right)$ terhadap kemampuan penyelesaian masalah matematika $(\mathrm{Y})$. Hal tersebut terlihat pada kontribusi langsung konsep diri $\left(\mathrm{X}_{1}\right)$ terhadap kemampuan penyelesaian masalah 
matematika (Y) hanya sebesar $(-0,070)^{2} \times 100 \%=0,49 \%$ sisanya sebesar $99,51 \%$ dipengaruhi oleh faktor lain yang tidak dijelaskan dalam penelitian ini.

\section{Pengaruh Langsung Konsep Diri $\left(X_{1}\right)$ Terhadap Kecemasan Belajar $\left(X_{2}\right)$}

Ditemukan bahwa terdapat korelasi yang cukup signifikan konsep diri ( $\left.\mathrm{X}_{1}\right)$ terhadap kecemasan belajar $\left(\mathrm{X}_{2}\right)$. Hal ini ditunjukkan oleh angka koefisien korelasi $\left(r_{12}\right)$ sebesar 0,505.

Namun demikian, diketahui pula bahwa koefisien jalur $\mathrm{X}_{1}$ terhadap $\mathrm{X}_{2}\left(p_{12}\right)$ sebesar 0,505 dan setelah diuji dengan uji-t pengaruh tersebut nyata/ signifikan. Hal tersebut menunjukkan ada pengaruh langsung yang signifikan konsep diri $\left(\mathrm{X}_{1}\right)$ terhadap kecemasan belajar $\left(\mathrm{X}_{2}\right)$. Hal tersebut terlihat pada kontribusi langsung konsep diri $\left(\mathrm{X}_{1}\right)$ terhadap kemampuan penyelesaian masalah matematika $(\mathrm{Y})$ hanya sebesar $(0,505)^{2} \mathrm{X}$ $100 \%=25,51 \%$ sisanya sebesar $74,49 \%$ dipengaruhi oleh faktor lain yang tidak dijelaskan dalam penelitian ini.

\section{Pengaruh Tidak Langsung Konsep Diri $\left(X_{1}\right)$ Terhadap Kemampuan Penyelesaian Masalah Matematika (Y) Melalui Kecemasan Belajar $\left(\mathbf{X}_{2}\right)$}

Dari hasil perhitungan menunjukkan bahwa koefisien jalur $\mathrm{X}_{1}$ terhadap $\mathrm{Y}\left(p_{321}\right)$ melalui kecemasan belajar $\left(\mathrm{X}_{2}\right)$ sebesar -0,0934dan setelah diuji dengan uji-t pengaruh tersebut tidak nyata/ signifikan. Hal tersebut menunjukkan tidak ada pengaruh langsung yang signifikan konsep diri $\left(\mathrm{X}_{1}\right)$ terhadap kemampuan penyelesaian masalah matematika (Y) melalui kecemasan belajar $\left(\mathrm{X}_{2}\right)$. Hal tersebut terlihat pada kontribusi langsung konsep diri $\left(\mathrm{X}_{1}\right)$ terhadap kemampuan penyelesaian masalah matematika $(\mathrm{Y})$ melalui kecemasan belajar $\left(\mathrm{X}_{2}\right)$ hanya sebesar $(-0,0934)^{2}$ x $100 \%=0,0872 \%$ sisanya sebesar 99,91\% dipengaruhi oleh faktor lain yang tidak dijelaskan dalam penelitian ini.

\section{PENUTUP}

\section{Simpulan}

1. Tidak terdapat pengaruh langsung yang signifikan konsep diri $\left(\mathrm{X}_{1}\right)$ terhadap kemampuan pemecahan masalah matematika (Y). Hal ini dibuktikan oleh pengujian hipotesis 1 melalui pendekatan analisis regresi, yakni diperoleh nilai $t_{\text {hitung }}$ sebesar 1,932 sedangkan $t_{\text {tabel }}$ sebesar 1,986.

2. Tidak terdapat pengaruh langsung yang signifikan kecemasan belajar $\left(\mathrm{X}_{2}\right)$ terhadap kemampuan pemecahan masalah matematika(Y). Hal ini dibuktikan oleh pengujian hipotesis 2, yakni diperoleh nilai $t_{\text {hitung }}$ sebesar $-1,185$ sedangkan $t_{\text {tabel }}$ sebesar 1,986.

3. Terdapat pengaruh langsung yang signifikan konsep diri $\left(\mathrm{X}_{1}\right)$ terhadap kecemasan belajar $\left(\mathrm{X}_{2}\right)$. Hal ini dibuktikan oleh pengujian hipotesis 3 , yakni diperoleh nilai $t_{\text {hitung }}$ sebesar 5,642 sedangkan $t_{\text {tabel }}$ sebesar 1,986.

4. Tidak terdapat pengaruh tidak langsung yang signifikan konsep diri $\left(\mathrm{X}_{1}\right)$ terhadap kemampuan pemecahan masalah matematika $(\mathrm{Y})$ melalui kecemasan belajar $\left(\mathrm{X}_{2}\right)$. Hal ini dibuktikan oleh pengujian hipotesis 4 yakni diperoleh nilai $t_{\text {hitung }}$ sebesar 0,8094 sedangkan $t_{\text {tabel }}$ sebesar 1,986.

\section{SARAN}

1. Guru matematika hendaknya memperbanyak berlatih untuk dapat membiasakan diri berbaur bersama peserta didik sehingga mengetahui kemampuan serta kesulitan atau masalah yang menyangkut kasus matematika sehingga dapat memberikan perubahan pada cara penyampaian materi'

2. Diperlukan kerjasama antar guru matematika dalam mengoptimalkan kemampuan peserta didik dalam menyelesaikan masalah matematikasebagai sarana tukar 
pengalaman mengajar sesuai strategi pembelajaran dan metode yang digunakan oleh masing-masing guru.

3. Pembekalan berbagai teori, konsep dan aspek yang dimiliki guru yang berhubungan dengan mata pelajaran terkait hendaknya dikembangkan dan ditingkatkan

4. Guru hendaknya dapat menciptakan suasan belajar yang kondusif yang dapat meningkatkan gairah belajar peserta didik.

\section{DAFTAR PUSTAKA}

Agustian, Hendriati. 2006. Psikologi Perkembangan.Bandung: Refika Aditama.

Al-Badri. 2012. "Pemecahan Masalah dalam Pembelajaran Matematika". http://pengalaman-al-badri.blogspot.com. 9 Mei 2014.

Arikunto, Suharsimi. 2010. Prosedur Penelitian Suatu Pendekatan Praktik. Jakarta: Rineka Cipta.

Arikunto, Suharsimi. 2013. Dasar-Dasar Evaluasi Pendidikan. Jakarta: Bumi Aksara.

Departemen Pendidikan Nasional. 2008. Ensiklopedi Kebahasaan Indonesia. Jakarta: Balai Pustaka.

Dimyati dan Mujiono. 2009. Belajar dan Pembelajaran. Jakarta: Rineka Cipta.

Djamarah, Syaiful. 2005. Guru dan Anak Didik. Jakarta: Rineka Cipta.

Hasan Alwi, dkk.2004. Kamus Besar Bahasa Indonesia. Jakarta: Balai Pustaka.

Hasan, Iqbal. 2004. Analisis Data Penelitian dengan Statistik. Jakarta: Bumi Aksara.

Hayati, Sri. 2014. Pengaruh Konsep Diri, Kemandirian Belajar dan Sikap Siswa pada Matematika terhadap Prestasi Belajar Matematika. Skripsi. Universitas Indraprasta PGRI Jakarta.

Hutagulung, Inge. 2007. Pengembangan Kepribadian Tinjauan Praktis Menuju Pribadi Positif. Jakarta: Indeks.

I.A, Suparman. 2013. Aplikasi Komputer dalam Penyusunan Karya Ilmiah. Tangerang: Pustaka Mandiri.

Kementrian Pendidikan dan Kebudayaan. 2014. MATEMATIKA Edisi Revisi 2014 SMA/MA/SMK/MAK Kelas X Semester 1. Jakarta.

Leonard dan Supardi U.S. 2010. Pengaruh konsep diri, sikap siswa pada matematika dan kecemasan siswa terhadap hasil belajar matematika. Cakrawala Pendidikan, XXIX (3).

Nana Sudjana dan Ahmadi Rivai. 2007. Media Pembelajaran. Jakarta: Sinar Baru Algesindo.

Noor, Juliansyah. 2011. Metodologi Penelitian: Skripsi, Tesis, Disertasi dan Karya Ilmiah. Jakarta: Kencana.

Omrod, Jeanne Ellis. 2009. Psikologi Pendidikan. Jakarta: Erlangga.

Ponohardjo. 2008. Perencanaan Penelitian Pendidikan Matematika. Badan Penerbitan Universitas Pancasakti Tegal.

Ponohardjo. 2009. Profesi Kependidikan. Badan Penerbitan Universitas Pancasakti Tegal.

Purwanto. 2010. Metodologi Penelitian Kuantitatif untuk Psikologi dan Pendidikan.Yogyakarta: Pustaka Pelajar.

Rakhmat, Jalaluddin. 2009. Psikologi Komunikasi. Bandung: Remaja Rosdakarya.

Sagala, Syaiful. 2010. Konsep dan Makna Pembelajaran. Bandung: Alfabeta.

Sasmoko. 2004. Metode Penelitian. Jakarta: UKI Press.

Slameto. 2010. Belajar dan Faktor-faktor yang Mempengaruhinya. Jakarta: Rineka Cipta. 
Soraya, Nova. 2013. Pengaruh Konsep Diri, Kecemasan Belajar dan Persepsi pada Iklim Sekolah terhadap Prestasi Belajar Matematika. Skripsi. Universitas Indraprasta PGRI Jakarta.

Sudijono, Anas. 2011. Pengantar Evaluasi Pendidikan. Jakarta: Raja Grafindo Persada. Sugiyono. 2010. Metode Penelitian Pendidikan. Bandung: Alfabeta.

Supardi. 2012. Aplikasi Statistika dalam Penelitian. Jakarta: Ufuk Publishing House.

Susongko, Purwo. 2010. Penilaian Hasil Belajar. Badan Penerbitan Universitas Pancasakti Tegal.

Suyatno. 2014. Pengaruh Media Pembelajaran dan Konsep Diri Siswa terhadap Hasil Belajar Matematika. Skripsi. Universitas Indraprasta PGRI Jakarta.

Virgana. 2014. Buku Panduan Penulisan Tesis. Jakarta: Pustaka Mandiri.

Virgana. 2014. Manajemen Kurikulum MIPA.Tangerang: Pustaka Mandiri. 